\title{
Inflation Targeting at 20: \\ Achievements and Challenges
}

Scott Roger 


\title{
IMF Working Paper
}

\author{
$\mathrm{MCM}$

\section{Inflation Targeting at 20: Achievements and Challenges}

\section{Prepared by Scott Roger}

Authorized for distribution by Karl Habermeier

October 2009

\begin{abstract}
This paper provides an overview of inflation targeting frameworks and macroeconomic performance under inflation targeting. Inflation targeting frameworks are generally quite similar across countries, and a broad consensus has developed in favor of "flexible" inflation targeting. The evidence shows that, although inflation target ranges are missed frequently in most countries, the inflation and growth performance under inflation targeting compares very favorably with performance under alternative frameworks. Inflation targeters also tentatively appear to be coping better with the commodity price and financial shocks in 2007-2009 than non-inflation targeters. Key issues going forward include adapting inflation targeting to emerging market and developing countries, and incorporating financial stability issues into the framework.
\end{abstract}

\section{This Working Paper should not be reported as representing the views of the IMF. \\ The views expressed in this Working Paper are those of the author(s) and do not necessarily represent those of the IMF or IMF policy. Working Papers describe research in progress by the author(s) and are published to elicit comments and to further debate.}

JEL Classification Numbers: E31, E52

Keywords: inflation targeting, monetary policy

Author's E-Mail Address: sroger@imf.org 


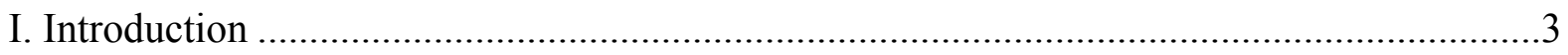

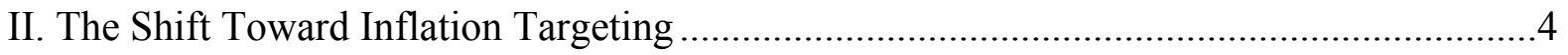

III. Elements of Inflation Targeting Frameworks …..................................................

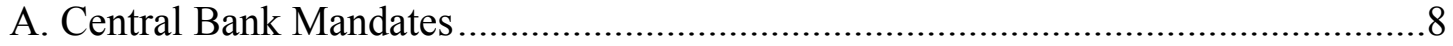

B. Policy Accountability and Transparency .....................................................

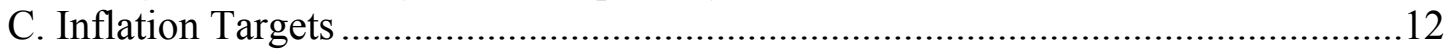

D. Policy Formulation and Implementation......................................................... 13

IV. Performance Under Inflation Targeting.............................................................. 14

A. Performance in Achieving Inflation Targets...................................................... 14

B. Macroeconomic Performance under Alternative Monetary Policy Regimes..........17

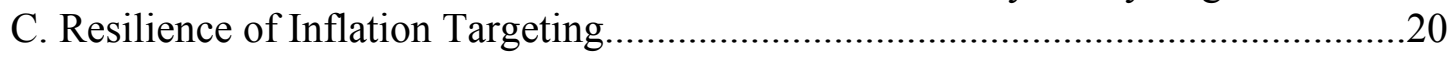

V. Issues and Challenges for Inflation Targeting ......................................................23

A. Adapting Inflation Targeting to Emerging Market and Developing Countries ......23

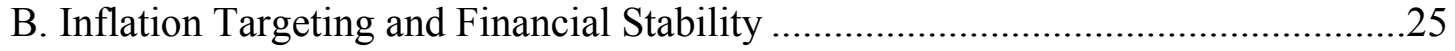




\section{INTRODUCTION ${ }^{1,2}$}

1. Inflation targeting (IT) was first adopted in the early 1990 s by industrial countries, but is being adopted by a growing number of emerging market and developing countries. As of mid-2009, 26 countries are classified as inflation targeters, including 11 high income countries and 15 lower income emerging market and developing countries. This paper provides a review of the experience with IT, together with an overview of some issues and challenges facing its future.

2. Section II briefly documents the spread of IT and, especially, the increasing dominance of emerging market and developing country inflation targeters; a trend that is expected to continue.

3. Section III begins with an overview of the major elements of IT frameworks, including: (i) the specification of the inflation target and the handling of policy trade-offs; (ii) governance and decision-making frameworks; and (iii) communications and accountability arrangements. Broadly speaking, the analysis finds that a fairly standard model of IT has emerged. IT specifications are generally quite similar - perhaps too much so - and a broad consensus has developed in favor of "flexible" IT, which takes not only inflation but also output considerations into account in policy formulation. Policy accountability and communications arrangements also appear to be converging on an increasingly transparent model.

4. Section IV reviews macroeconomic performance under IT, focusing on three main issues: (i) how well countries have done in meeting their inflation targets; (ii) whether IT has tended to deliver better macroeconomic performance than alternative policy frameworks; and (iii) whether IT has delivered better macroeconomic results than alternative frameworks in response to the global commodity price and financial shocks. The results indicate that IT ranges are missed frequently in most countries, but especially in countries that are in the process of disinflation. Tentative evidence also indicates that inflation targeters have coped better with the commodity price and financial shocks in 2007-2009 than non-inflation targeters.

5. Section V concludes with a discussion of issues and challenges in IT. These include challenges in adapting IT to emerging market and developing countries and more effectively incorporating financial stability issues into IT frameworks.

\footnotetext{
${ }^{1}$ An earlier version of this paper was presented at the Norges Bank 2009 Monetary Policy Conference "Inflation Targeting Twenty Years On," 11-12 June 2009, Oslo, Norway. I am grateful to conference participants, as well as IMF colleagues, for useful comments and suggestions. Remaining errors and omissions are my own.

${ }^{2}$ I would like to thank Claudia Jadrijevic Zenteno for excellent research assistance.
} 


\section{The SHIFT TOWARD INFLATION TARGETING}

\section{Since New Zealand adopted IT in 1989, twenty-nine countries have introduced} IT frameworks (Table 1). ${ }^{3,4}$ In addition, several other central banks, including the European Central Bank (ECB), the Swiss National Bank, and the Federal Reserve in the United States, have moved toward regimes that have many of the attributes of IT. Through the 1990s, IT was almost entirely confined to advanced "industrial" countries. Since the late 1990s, however, an increasing number of emerging market and developing economies have adopted the framework and such countries are now the substantial majority of inflation targeters.

7. The spread of IT has often been spurred by exchange rate crises. As shown in Figure 1, exchange rate pegs of various kinds accounted for two-thirds of monetary policy regimes in industrial countries in 1989. ${ }^{5}$ The ERM crisis in 1992 served as a spur to the adoption of IT in Europe. Among emerging market economies, the shift toward IT has been a more gradual process. In Latin America, movement toward IT began in the early 1990s, but full-fledged IT was adopted only in the late 1990s and early 2000s, following the 1998 financial crisis. In Europe, the transition economies of Central and Eastern Europe began introducing IT in the late 1990s as part of their comprehensive economic reforms, while in East Asia, IT began to be adopted in the early 2000s, as countries emerged from monetary targeting under Fund-supported programs following the 1997 Asian financial crisis. At least until the global financial crisis erupted, IT was expected to continue to spread among emerging markets and developing economies. ${ }^{6}$ The outlook for the spread of IT now seems likely to depend very much on how well the framework is perceived to have coped with the oil price shock and the subsequent global financial shock.

\footnotetext{
${ }^{3}$ New Zealand passed the legislation for IT in late 1989, with implementation from the beginning of 1990 .

${ }^{4}$ Finland and Spain ceased IT when they entered the euro area in January 1999, and Slovakia ceased IT in January 2009 with its ERM II entry.

${ }^{5}$ To facilitate comparisons over time, the figures include separately the various republics of the former Soviet Union and Yugoslavia, which became independent during the 1990s. In the pre-independence period each of the constituent republics is treated as having the same monetary policy as the federation. This avoids having the break-up of the federations affecting the relative proportions of different policy regimes. The establishment of the euro zone is shown as a shift by ERM countries to from exchange rate targeting to a multiple targets framework.

${ }^{6}$ IMF discussions with member states in 2006 suggested that the number of inflation targeters in developing and emerging market economies was likely to increase four-fold over the next decade, consistent with the estimate by Husain, Mody, and Rogoff (2005) that the number of countries with exchange rate pegs may almost halve in the next $10-15$ years.
} 
Figure 1. Evolution of Monetary Policy Regimes, 1989-2008

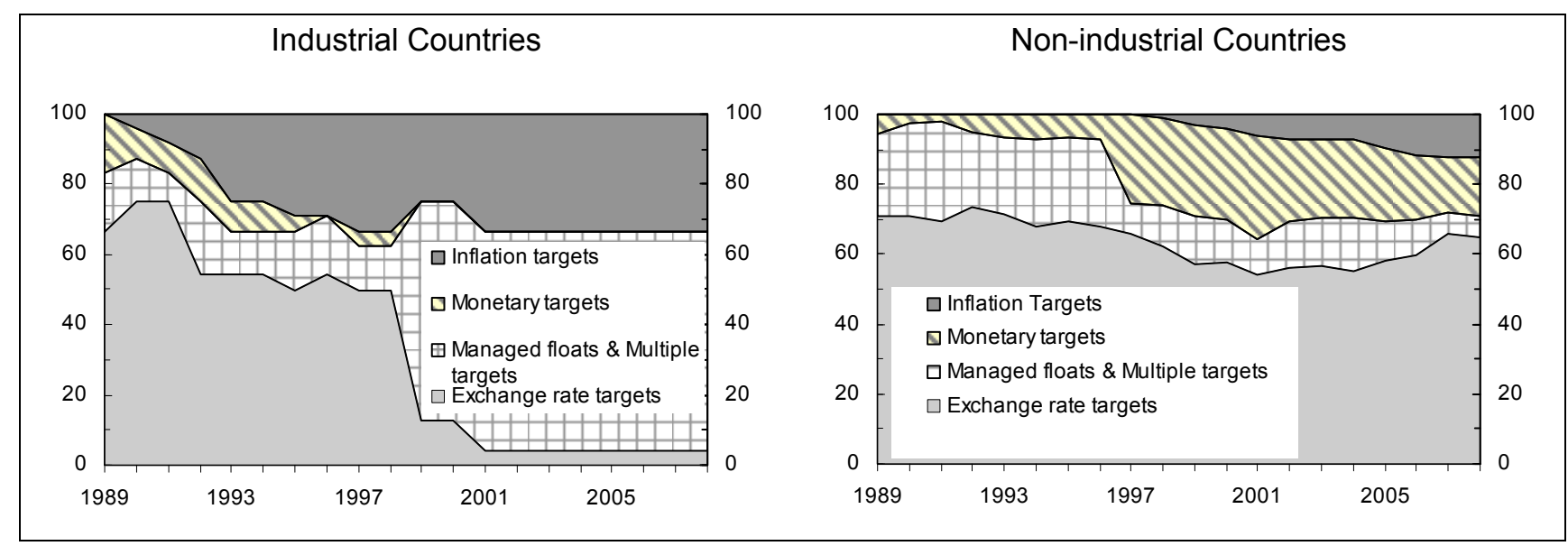

Source: IMF.

8. In most countries adopting IT, there has been an initial phase of disinflation.

This phase has typically involved setting year-by-year targets for reducing inflation.

Disinflation has typically begun from a level of about 4.8 percent among high income countries, and from 6.5 percent in low income countries. ${ }^{7}$ Once inflation has been brought down, the regime shifts to targeting stable, multi period, or indefinite horizon targets, typically around 3 percent. In about one-third of cases, however, stable inflation targets were adopted at the outset.

\footnotetext{
${ }^{7}$ High and low income country groups are based on the World Development Indicators classification of the World Bank.
} 
Table 1: Adoption of Inflation Targeting

\begin{tabular}{|c|c|c|c|c|c|}
\hline Country & $\begin{array}{c}\text { Effective IT } \\
\text { adoption date }\end{array}$ & $\begin{array}{c}\text { CPI inflation } \\
\text { rate at start } \\
\text { of } \\
\text { disinflation }\end{array}$ & $\begin{array}{c}\text { Disinflation } \\
\text { period }\end{array}$ & $\begin{array}{c}\text { CPI inflation } \\
\text { rate at start } \\
\text { of stable } \\
\text { targeting }\end{array}$ & Stable IT period \\
\hline New Zealand ${ }^{1}$ & 1990Q1 & 3.3 & 1990Q1-1992Q4 & 1.8 & 1993Q1-present \\
\hline Canada $^{1}$ & 1991M2 & 6.9 & 1991M2-1994M12 & 0.2 & 1995M1-present \\
\hline United Kingdom $^{1}$ & 1992M10 & & & 4.0 & 1992M10-present \\
\hline Sweden $^{1}$ & 1993M1 & & & 1.8 & 1993M1-present \\
\hline Finland $^{1}$ & 1993M2 & & & 2.6 & 1993M2-1998M12 \\
\hline Australia $^{1}$ & 1993M4 & & & 2.0 & 1993Q2-present \\
\hline Spain $^{1}$ & 1995M1 & 4.2 & 1995M1-1997M12 & & 1998M1-1998M12 \\
\hline Czech Republic $^{1}$ & 1997M12 & 6.8 & 1997M12-2001M12 & 4.1 & 2002M1-present \\
\hline Israel $^{1}$ & 1997M6 & 8.1 & 1997M6-2002M12 & 6.5 & 2003M1-present \\
\hline Poland $^{2}$ & 1998M10 & 10.6 & 1998M10-2003M12 & 1.7 & 2004M1-present \\
\hline Brazil $^{2}$ & 1999M6 & 3.3 & 1999M6-2005M12 & 5.7 & 2006M1-present \\
\hline Chile $^{2}$ & 1999M9 & 3.2 & 1999M9-2000M12 & 4.5 & 2001M1-present \\
\hline Colombia $^{2}$ & 1999M9 & 9.3 & 1999M9-present & & \\
\hline South Africa ${ }^{2}$ & $2000 \mathrm{M} 2$ & & & 2.6 & 2000M2-present \\
\hline Thailand $^{2}$ & 2000M5 & & & 0.8 & 2000M5-present \\
\hline Korea $^{1}$ & 2001M1 & & & 2.8 & 2001M1-present \\
\hline Mexico $^{2}$ & 2001M1 & 9.0 & 2001M1-2002M12 & 5.7 & 2003M1-present \\
\hline Iceland $^{1}$ & $2001 \mathrm{M} 3$ & 4.1 & 2001M3-2003M12 & 2.7 & 2004M1-present \\
\hline Norway $^{1}$ & 2001M3 & & & 3.6 & 2001M3-present \\
\hline Hungary $^{1}$ & 2001M6 & 10.8 & 2001M6-2006M12 & 6.5 & 2007M1-present \\
\hline Peru $^{2}$ & $2002 \mathrm{M} 1$ & & & -0.1 & 2002M1-present \\
\hline Philippines $^{2}$ & $2002 \mathrm{M} 1$ & 4.5 & 2002M1-present & 1.8 & \\
\hline Guatemala $^{2}$ & $2005 \mathrm{M} 1$ & 9.2 & 2005M1-present & 0.2 & \\
\hline Slovakia $^{1}$ & $2005 \mathrm{M} 1$ & 5.8 & 2005M1-2008M12 & & $\begin{array}{l}\text { IT concluded in } \\
2008 \mathrm{M} 12\end{array}$ \\
\hline Indonesia $^{2}$ & $2005 \mathrm{M} 7$ & 7.4 & 2005M7-present & & \\
\hline Romania $^{2}$ & $2005 \mathrm{M} 8$ & 9.3 & 2005M8-present & & \\
\hline Turkey $^{2}$ & 2006M1 & 7.7 & 2006M1-present & & \\
\hline Serbia $^{2}$ & 2006M9 & 10.8 & 2006M9-present & & \\
\hline Ghana $^{2}$ & 2007M5 & 10.5 & 2007M5-present & & \\
\hline All countries & & 5.7 & & 3.1 & \\
\hline 14 High income $^{1}$ & & 4.8 & & 3.2 & \\
\hline 15 Low income ${ }^{1}$ & & 6.5 & & 3.0 & \\
\hline
\end{tabular}

Source: Author's calculations.

1/ High income countries, based on World Bank Development Indicators classification; 2/ Low income countries, based on World Bank Development Indicators classification. 


\section{ELEMENTS OF INFLATION TARGETING FRAMEWORKS ${ }^{8}$}

\section{The emergence of IT frameworks draws on a number of insights gained from} theory and practical experience. ${ }^{9}$ On a practical level, the decision to pursue inflation targets directly has often resulted from the failure of indirect approaches, based on either monetary or exchange rate targeting, to yield acceptable results. ${ }^{10}$ Both theory and experience also point towards some basic guiding principles for a monetary policy framework. These include: (i) the central bank cannot consistently pursue and achieve multiple goals with only one basic instrument - the policy interest rate; (ii) over the long-term, monetary policy can control nominal but not real variables; (iii) high inflation harms growth and the equitable distribution of income; and (iv) expectations and credibility matter greatly for the effectiveness of monetary policy and the potential short-term trade-offs between inflation and other macroeconomic objectives.

10. These insights pointed towards a policy framework in which monetary policy is assigned a clear and credible objective of achieving and maintaining low inflation. In addition, and drawing upon developments in the principal-agent literature, the framework recognized that policy credibility would be enhanced by strengthening the operational autonomy of the central bank, while at the same time ensuring a high degree of policy transparency and accountability.

\section{From the outset, IT frameworks have included the following basic elements: ${ }^{11}$}

- An explicit central bank mandate to pursue price stability as the primary objective of monetary policy, together with accountability for performance in achieving the objective;

- $\quad$ A high degree of transparency of monetary policy strategy and implementation;

- $\quad$ Explicit quantitative targets for inflation; and

\footnotetext{
${ }^{8}$ This section draws on Heenan and others (2006).

${ }^{9}$ A revealing review of the development of the original IT framework in New Zealand is provided by Reddell (1999).

${ }^{10}$ In the case of monetary targets, instability in money demand relationships-commonly associated with financial system reforms and opening of capital markets - undermined the usefulness of monetary aggregates as policy guides. In the case of exchange rate pegs, real exchange rate targets provided no nominal anchor, while nominal exchange rate pegs left both prices and activity vulnerable to shocks affecting equilibrium real exchange rates.

${ }^{11}$ See also Mishkin (2004).
} 
- $\quad$ Policy actions based on a forward-looking assessment of inflation pressures, taking into account a wide array of information.

\section{A. Central Bank Mandates}

12. The objective of price stability is frequently embedded in central bank legislation and the target specification. However, legislated goals often do not clearly define price stability as the primary objective of monetary policy (Table 2). Consequently, the specification of the inflation target plays a particularly important role in defining the IT mandate. In most countries, target specifications are established jointly between the central bank and the government, but even in countries where one or the other has sole authority to specify the target, close consultation is the norm.

\section{IT central banks typically have a high degree of instrument or operational}

autonomy. In several emerging market economies, revisions to central bank acts have explicitly ruled out the provision of credit to the government, eliminated government vetoes over policy decisions, and strengthened measures to insulate central bank policy decisionmakers from potential pressures from the government.

14. Even where there are limits on instrument autonomy, these do not appear to be binding in practice. As indicated in Table 2, in many countries where IT has been implemented successfully, instrument autonomy is, in principle, potentially constrained by the potential for central bank financing of government, government powers to override the central bank's instrument-setting decisions, or direct participation by government officials in monetary policy decision-making. This underscores that de jure autonomy matters less than de facto autonomy. In this regard, a strong government commitment to the inflation-targeting framework is crucial.

\section{B. Policy Accountability and Transparency}

\section{Central bank accountability for performance in relation to the inflation target is} a natural corollary of autonomy in policy implementation, and helps to reinforce such autonomy. Having to account for inflation performance provides strong incentives for the central bank to focus on meeting its targets and to communicate its decisions and actions transparently. The need to explain policy decisions to the public also serves as a powerful internal discipline on the central bank's approach to policy analysis and decision-making. Public accountability also provides an incentive for the central bank to resist external pressures to let factors outside its remit unduly influence policy. From this perspective, high standards of policy accountability help the central bank to maximize its autonomy to pursue its mandate, while minimizing its incentives to be distracted by other considerations. 
Table 2. Central Bank Autonomy

\begin{tabular}{|c|c|c|c|c|c|}
\hline Country & Goal Autonomy & $\begin{array}{c}\text { Target } \\
\text { Autonomy }\end{array}$ & & Instrument $A$ & 10my \\
\hline & Legislated Goal & $\begin{array}{l}\text { Target } \\
\text { Specification 1/ }\end{array}$ & $\begin{array}{l}\text { Government } \\
\text { Override 2/ }\end{array}$ & $\begin{array}{l}\text { Credit to } \\
\text { Government 3/ }\end{array}$ & $\begin{array}{l}\text { Gov't Participation in } \\
\text { Policymaking } 4 /\end{array}$ \\
\hline Australia & Multiple goals & $\mathrm{G}+\mathrm{CB}$ & Yes & Yes & Voting member \\
\hline Brazil & Inflation target & G & No & No & No \\
\hline Canada & Multiple goals & $\mathrm{G}+\mathrm{CB}$ & Yes & Yes, limited & Non-voting \\
\hline Chile & $\begin{array}{l}\text { Price }+ \text { financial } \\
\text { stability }\end{array}$ & $\mathrm{CB}$ & Yes & No & Non-voting ${ }^{5}$ \\
\hline Colombia & Price stability & $\mathrm{CB}$ & Yes & No & Voting member \\
\hline $\begin{array}{l}\text { Czech } \\
\text { Republic }\end{array}$ & Price stability & $\mathrm{G}+\mathrm{CB}$ & No & No & Non-voting \\
\hline Ghana & Price stability & $\mathrm{G}+\mathrm{CB}$ & No & Yes, limited & Voting member \\
\hline Guatemala & Price stability & $\mathrm{CB}$ & No & No & Voting member \\
\hline Hungary & Price stability & $\mathrm{G}+\mathrm{CB}$ & No & No & Non-voting \\
\hline Iceland & Price stability & $\mathrm{G}+\mathrm{CB}$ & No & No & No \\
\hline Indonesia & Currency stability & $\mathrm{G}+\mathrm{CB}$ & No & No & No \\
\hline Israel & Price stability & G & No & No & No \\
\hline Korea & Price stability & $\mathrm{G}+\mathrm{CB}$ & No & Yes & Non-voting \\
\hline Mexico & Price stability & $\mathrm{CB}$ & No & Yes & Non-voting \\
\hline New Zealand & Price stability & $\mathrm{G}+\mathrm{CB}$ & Yes & Yes & No \\
\hline Norway & Low, stable inflation & G & Yes & No & No \\
\hline Peru & Monetary stability & $\mathrm{CB}$ & No & No & Voting member \\
\hline Philippines & Price stability & $\mathrm{G}+\mathrm{CB}$ & No & Yes, limited & Voting member \\
\hline Poland & Price stability & $\mathrm{CB}$ & No & No & Non-voting \\
\hline Romania & Price stability & $\mathrm{G}+\mathrm{CB}$ & No & No & No \\
\hline Serbia & Low, stable inflation & $\mathrm{G}+\mathrm{CB}$ & No & Yes, limited & Non-voting \\
\hline Slovakia & Price stability & $\mathrm{CB}$ & No & No & No \\
\hline South Africa & Currency stability & $\mathrm{G}+\mathrm{CB}$ & Yes & Yes & No \\
\hline Sweden & Price stability & $\mathrm{CB}$ & No & No & Non-voting \\
\hline Thailand & Monetary stability & $\mathrm{CB}$ & No & Yes & No \\
\hline Turkey & Price Stability & $\mathrm{G}+\mathrm{CB}$ & No & No & Non-voting \\
\hline $\begin{array}{l}\text { United } \\
\text { Kingdom }\end{array}$ & Price stability & G & Yes & No & Non-voting \\
\hline
\end{tabular}

Notes and Sources: 1/ $\mathrm{G}=$ Government; $\mathrm{CB}=$ Central Bank; 2/ Roger and Stone (2005), Table 3; 3/ Tuladhar (2005), Table 6; 4/ Tuladhar (2005), Table 3; 5/ Finance Minister may delay implementation of decisions for two weeks. 
16. Mechanisms for providing central bank policy accountability vary across countries, with some having quite formal arrangements and others less so (Table 3 ). ${ }^{12}$ The main mechanisms used to hold the central bank accountable for its policy performance and actions include:

- $\quad$ Publication of regular inflation or monetary policy reports;

- $\quad$ Publication of special reports or open letters in the event of significant misses of the target;

- Use of "escape" clauses to limit central bank accountability in particular circumstances, as well as to indicate, in advance, how policy will react to certain kinds of shocks;

- $\quad$ Parliamentary testimony by the central bank governor;

- $\quad$ Publication of minutes of policy meetings within a reasonable time frame; and

- $\quad$ Press conferences and analyst briefings following release of policy decisions and monetary policy reports.

17. Over time, policy accountability has tended to become more forward looking. In the early years of IT, accountability arrangements tended to stress fairly formal accountability procedures in the event of target misses, such as the use of "escape clauses" to limit central bank accountability in certain circumstances, as well as special reporting requirements in the event of target misses. In more recent years, the trend appears to be to put more emphasis on explaining policy decisions to the public in a timely manner and deemphasizing the importance of target misses. To some extent, this may reflect the fact that keeping inflation within a fairly narrow range has proven harder, or perhaps less sensible, than was believed in the early days. More fundamentally, it may also reflect the view that, with a forward-looking policy framework, the focus of accountability should be primarily on forward-looking decision-making, and less on outcomes which are affected by many factors outside the close control of the central bank.

\section{Effective, forward-looking accountability depends heavily on policy}

transparency. This includes, in particular, providing a clearly explained picture of the policy transmission mechanism, the macroeconomic outlook, and risks and uncertainties that need to be taken into account in setting policy. It also requires a better understanding of monetary policy by key audiences. As a consequence, IT central banks have moved to increase the transparency of policy-making, including through publication of inflation projections, publication of minutes of policy meetings, increased provision of information on websites, and so on. Practices vary widely, and many central banks are well short of best practice, but

\footnotetext{
${ }^{12}$ See Roger and Stone (2005), Tuladhar (2005), and Lybek and Morris (2004).
} 
the direction of movement is clearly towards greater emphasis on good communications and transparency.

Table 3. Central Bank Accountability and Policy Transparency

\begin{tabular}{|c|c|c|c|c|c|}
\hline Country & $\begin{array}{l}\text { Publication of } \\
\text { Policy Minutes }\end{array}$ & $\begin{array}{c}\text { Testimony / } \\
\text { Reporting to } \\
\text { Parliament }\end{array}$ & $\begin{array}{c}\text { Monetary } \\
\text { Policy Report }\end{array}$ & $\begin{array}{c}\text { Specific Reporting } \\
\text { on Large Target } \\
\text { Misses 1/ }\end{array}$ & $\begin{array}{c}\text { Use of Escape } \\
\text { Clauses 2/ }\end{array}$ \\
\hline Australia & No & Yes & Quarterly & No & No \\
\hline Brazil & Yes, 8-day lag & Yes & Quarterly & Yes & No \\
\hline Canada & No & Yes & $\begin{array}{l}\text { Semi-annual + } \\
\text { update }\end{array}$ & Yes & No \\
\hline Chile & Yes, 90-day lag & Yes & 3 per year & No & No \\
\hline Colombia & No & Yes & Quarterly & No & No \\
\hline $\begin{array}{l}\text { Czech } \\
\text { Republic }\end{array}$ & Yes & Yes & Quarterly & No & Explicit description \\
\hline Ghana & No & No & 4-6 per year & No & No \\
\hline Guatemala & No & Yes & Semi-annual & No & No \\
\hline Hungary & Yes & Yes & $\begin{array}{l}\text { Semi-annual + } \\
\text { update }\end{array}$ & No & No \\
\hline Iceland & No & No & Quarterly & Yes & No \\
\hline Indonesia & No & Yes & Quarterly & Yes & No \\
\hline Israel & Yes & Yes & Semi-annual & Yes & \\
\hline Korea & No & Yes & Semi-annual & No & No \\
\hline Mexico & No & Yes & Quarterly & No & No \\
\hline New Zealand & No & Yes & Quarterly & Yes & Explicit description \\
\hline Norway & No & Yes & 3 per year & No & No \\
\hline Peru & No & No & 3 per year & No & No \\
\hline Philippines & Yes & Yes & Quarterly & Yes & Explicit description \\
\hline Poland & No & Yes & Quarterly & No & Explicit description \\
\hline Romania & No & No & Quarterly & No & Explicit description \\
\hline Serbia & No & Yes & Quarterly & Yes & No \\
\hline Slovakia & No & No & Quarterly & No & Explicit description \\
\hline South Africa & No & No & Semi-annual & No & Explicit description \\
\hline Sweden & Yes & Yes & 3 per year & Yes & Explicit description \\
\hline Thailand & No & No & Quarterly & Yes & No \\
\hline Turkey & Yes & No & Quarterly & Yes & No \\
\hline $\begin{array}{l}\text { United } \\
\text { Kingdom }\end{array}$ & Yes & Yes & Quarterly & Yes & No \\
\hline
\end{tabular}

Notes \& Sources: 1/ Roger and Stone (2005), Table 3. 2/ Tuladhar (2005), Table 2. 


\section{Inflation Targets}

19. Specifications of inflation targets have become fairly standardized. In the early years of IT, there were considerable debates over the appropriate level and measure of inflation to target, whether to use point or range targets, the appropriate length of target horizons, and so on. Over time, however, target specifications appear to have converged on a fairly standardized — perhaps too standardized — set up:

- In almost all IT countries, the target is specified in terms of the 12-month change in the headline CPI. This reflects the familiarity of the public with the headline CPI, the importance of the CPI in the formation of inflation expectations and wage determination, and the fact that it is calculated by the statistics agency, and is typically the best quality of the price measures available. ${ }^{13}$

- Central banks also monitor and report on a range of measures of core inflation. Typically, these include exclusion-based measures (most commonly excluding exceptionally volatile prices, such as those for fresh fruit and vegetables, fuels, and non-market-determined or administered prices), and limited-influence measures such as trimmed means or the weighted median.

- Inflation target midpoints and ranges are similar for most countries (Figure 2). For countries that have adopted stable inflation targets, the midpoints of targets almost all lie between 2 to 3 percent. The target is usually specified as a point, with bands of plus or minus one percent. In a few countries, however, targets are defined as ranges, without specifying a center, while in others a point or "thick" point is specified without a range.

- $\quad$ Target horizons are also fairly standardized. During disinflation, targets are typically set for the end of year inflation rate, and set at least a year ahead. It is less common for the central bank to set out a full target path for disinflation, but several central banks indicate what the medium-term inflation objective is. Once disinflation has been accomplished, it is standard for countries to announce a shift from end-ofyear inflation targets to continuous or indefinite horizon targets.

\footnotetext{
${ }^{13}$ In the Czech Republic and Korea, targets were initially defined in terms of core or underlying inflation measures, but both have subsequently switched to headline inflation. Thailand is currently the only country setting its target in terms of core inflation.
} 
Figure 2. Inflation Target Levels and Bands in 2008

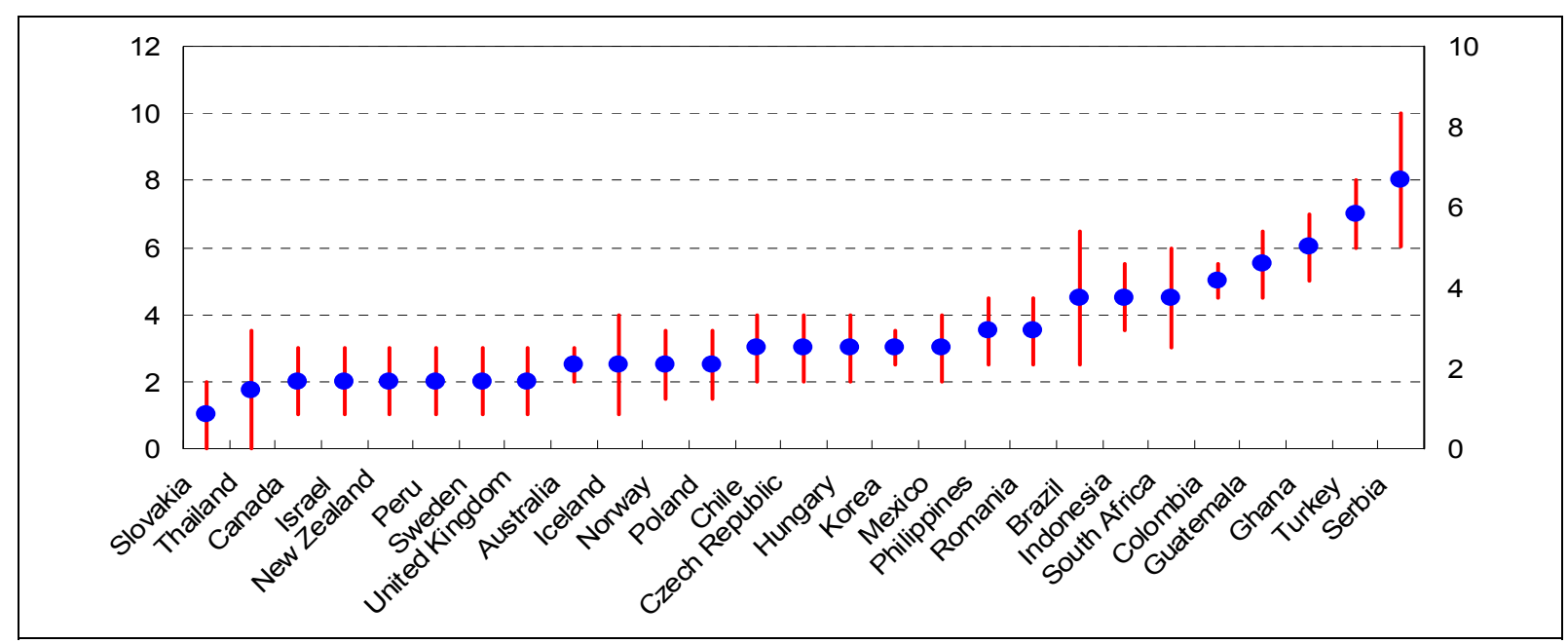

Source: Author's calculations.

\section{Policy Formulation and Implementation}

20. Details of policy formulation and implementation differ substantially across inflation targeters, but some basic features are generally similar. Inflation targeters all pursue "flexible" IT; the pursuit of inflation targets is tempered by a desire to minimize output volatility. This is partly reflected in the attention paid to output developments and prospects in inflation reports, the use of core inflation measures in policy analysis and formulation, and the typical emphasis on developing forecasting models that pay as much attention to forecasting growth as inflation. Inflation targeters also generally seek to take a forward-looking approach to policy formulation, and to that end, have worked to strengthen their forecasting and modeling capabilities. Clearly, however, there are marked differences in capacity, typically accentuated by very large differences in the availability of the timely, good quality data needed for forecasting purposes.

21. There are some important differences between inflation targeters. One is with respect to the role of the exchange rate in the policy framework. ${ }^{14}$ In several emerging market and developing country IT countries, the exchange rate has a much more prominent place in the policy framework than in most advanced economies, but even in some of the latter there is some evidence that exchange rate movements tend to elicit systematic policy reactions. ${ }^{15}$ There are also significant differences between inflation targeters in terms of financial sector development and in the ability of the central bank to implement policy using indirect,

\footnotetext{
${ }^{14}$ See Stone and others (2009).

${ }^{15}$ See e.g., Wei (2008).
} 
market-based instruments. Although the primary policy instrument is almost always the central bank interest rate, a number of countries also use reserve requirements or foreign exchange market intervention as supplementary instruments.

\section{Performance Under Inflation TARgeting}

\section{This section reviews evidence on three aspects of the performance of IT}

countries. The first is how well IT central banks have succeeded in meeting their stated inflation objectives. Second is a broader assessment of macroeconomic performance under IT compared with alternative policy frameworks. Third is how well IT countries have been coping with the most recent oil price and global financial shocks compared with other countries.

\section{A. Performance in Achieving Inflation Targets ${ }^{16}$}

\section{Inflation targeters miss their target ranges frequently, especially during the}

process of disinflation. Table 4 and Figure 3 present data on the inflation performance of 29 IT countries in relation to their targets. The analysis distinguishes between high and low income countries, and between performance during disinflation and in the context of stable inflation targets. The main results to highlight include:

- High income countries have typically started disinflating from around a 6 percent inflation rate, while emerging markets have usually started at a higher rate of around 8 percent. For both groups, however, stable IT has begun at around 3 percent.

- During disinflation, the performances of high and low income countries have been significantly different from each other. Although both groups of countries have missed their targets around 60 percent of the time, the misses by low income countries have been biased upward, while those of high income countries have been almost balanced. ${ }^{17}$

- The performance of both high and low income countries is generally better under stable IT. Inflation volatility is much less than during disinflation, which results in substantially fewer misses of inflation target ranges; in the case of high income

\footnotetext{
16 This section updates the analysis in Roger and Stone (2005), which was based on data for 22 countries through to mid-2004. The analysis in this paper covers 29 countries to end-2008.

${ }^{17}$ Moreover, given the high variance of inflation outcomes relative to target, if the average target range in low income countries had been of the same width as in high income countries, and on the assumptions of an approximately normal distribution of outcomes, misses of target ranges would have been much higher-close to 80 percent.
} 
countries, the frequency of misses falls to under half, while for low income countries the frequency of misses falls to just one-third. ${ }^{18}$

- Both the dispersion of inflation outcomes, and the bias with respect to the centers of target ranges are distinctly less with core inflation measures than with headline measures of inflation. Moreover, with core inflation measures, the inflation performances of high and low income countries are very similar, indicating that much of the difference seen in terms of headline inflation outcomes is attributable to larger and more frequent supply shocks in low income countries.

Table 4. Inflation Outcomes Relative to Targets, 1990-2008 1/

\begin{tabular}{|c|c|c|c|c|c|c|c|}
\hline & $\begin{array}{l}\text { Inflation } \\
\text { Rate at IT } \\
\text { Start } \\
\text { (percent) }\end{array}$ & $\begin{array}{c}\text { Target } \\
\text { Range } \\
\text { Width (+/-) } \\
\text { (percent) }\end{array}$ & $\begin{array}{c}\text { Mean } \\
\text { Deviation } \\
\text { from Range } \\
\text { Center } \\
\text { (percentage } \\
\text { points) }\end{array}$ & $\begin{array}{l}\text { Standard } \\
\text { Deviation } \\
\text { around Mean } \\
\text { Outcome } \\
\text { (percentage } \\
\text { points) }\end{array}$ & $\begin{array}{c}\text { Frequency of } \\
\text { Target Range } \\
\text { Misses } \\
\text { Total/below/above } \\
\text { (percentage of } \\
\text { outcomes) }\end{array}$ & $\begin{array}{c}\text { Average } \\
\text { Absolute } \\
\text { Magnitude } \\
\text { of Misses } \\
\text { (percentage } \\
\text { points) }\end{array}$ & $\begin{array}{c}\text { Persistence } \\
\text { of Deviations } \\
\text { from Range } \\
\text { Center } \\
\text { (months) }\end{array}$ \\
\hline All countries & 5.7 & 1.1 & 1.0 & 1.9 & $54.5 / 18.3 / 36.3$ & 1.5 & 8.5 \\
\hline High income 2/ & 4.8 & 1.0 & 0.1 & 1.3 & $49.1 / 23.9 / 25.3$ & 1.2 & 7.3 \\
\hline Low income $3 /$ & 6.5 & 1.2 & 1.8 & 2.4 & $59.6 / 13.0 / 46.6$ & 2.3 & 10.3 \\
\hline \multicolumn{8}{|l|}{ Disinflation Phase } \\
\hline All countries & 7.2 & 1.2 & 1.4 & 2.1 & $64.0 / 17.0 / 47.0$ & 1.8 & 10.2 \\
\hline High income 4/ & 6.3 & 1.0 & 0.1 & 1.7 & $59.6 / 29.4 / 30.2$ & 1.2 & 8.3 \\
\hline Low income 5/ & 7.9 & 1.3 & 2.3 & 2.4 & $66.9 / 8.8 / 58.1$ & 2.4 & 12.8 \\
\hline \multicolumn{8}{|c|}{ Stable Inflation Target Phase } \\
\hline All countries & 3.1 & 1.1 & 0.4 & 1.4 & $42.7 / 17.9 / 24.8$ & 1.0 & 6.9 \\
\hline High income 6/ & 3.2 & 1.0 & 0.4 & 1.3 & $46.6 / 21.4 / 25.2$ & 0.9 & 7.1 \\
\hline Low income 7/ & 3.0 & 1.3 & 0.5 & 1.6 & $35.5 / 11.3 / 24.2$ & 1.2 & 6.9 \\
\hline
\end{tabular}

Source: Author's calculations.

1/ Data calculated as equally-weighted averages of corresponding statistics for individual countries in relevant groups. Individual country figures are based on monthly data (quarterly for Australia and New Zealand).

2/ 14 countries: Australia, Canada, Czech Rep., Finland, Hungary, Iceland, Israel, Korea, New Zealand, Norway, Slovakia, Spain, Sweden, United Kingdom.

3/ 15 countries: Brazil, Chile, Colombia, Ghana, Guatemala, Indonesia, Mexico, Peru, Philippines, Poland, Romania, Serbia, South Africa, Thailand, Turkey.

4/ 8 countries: Canada, Czech Rep., Hungary, Iceland, Israel, New Zealand, Slovakia, Spain.

5/ 12 countries: Brazil, Chile, Colombia, Ghana, Guatemala, Indonesia, Mexico, Philippines, Poland, Romania, Serbia, Turkey.

6/ 13 countries: Australia, Canada, Czech Rep., Finland, Hungary, Iceland, Israel, Korea, New Zealand, Norway, Spain, Sweden, United Kingdom.

7/ 7 countries: Brazil, Chile, Mexico, Peru, Poland, South Africa, Thailand.

\footnotetext{
${ }^{18}$ If the low income countries had target ranges, on average, about the same width of those in high income countries, misses of target ranges would have been closer to 55 percent, all other things being equal.
} 
Figure 3. Distribution of Inflation Outcomes Relative to Targets

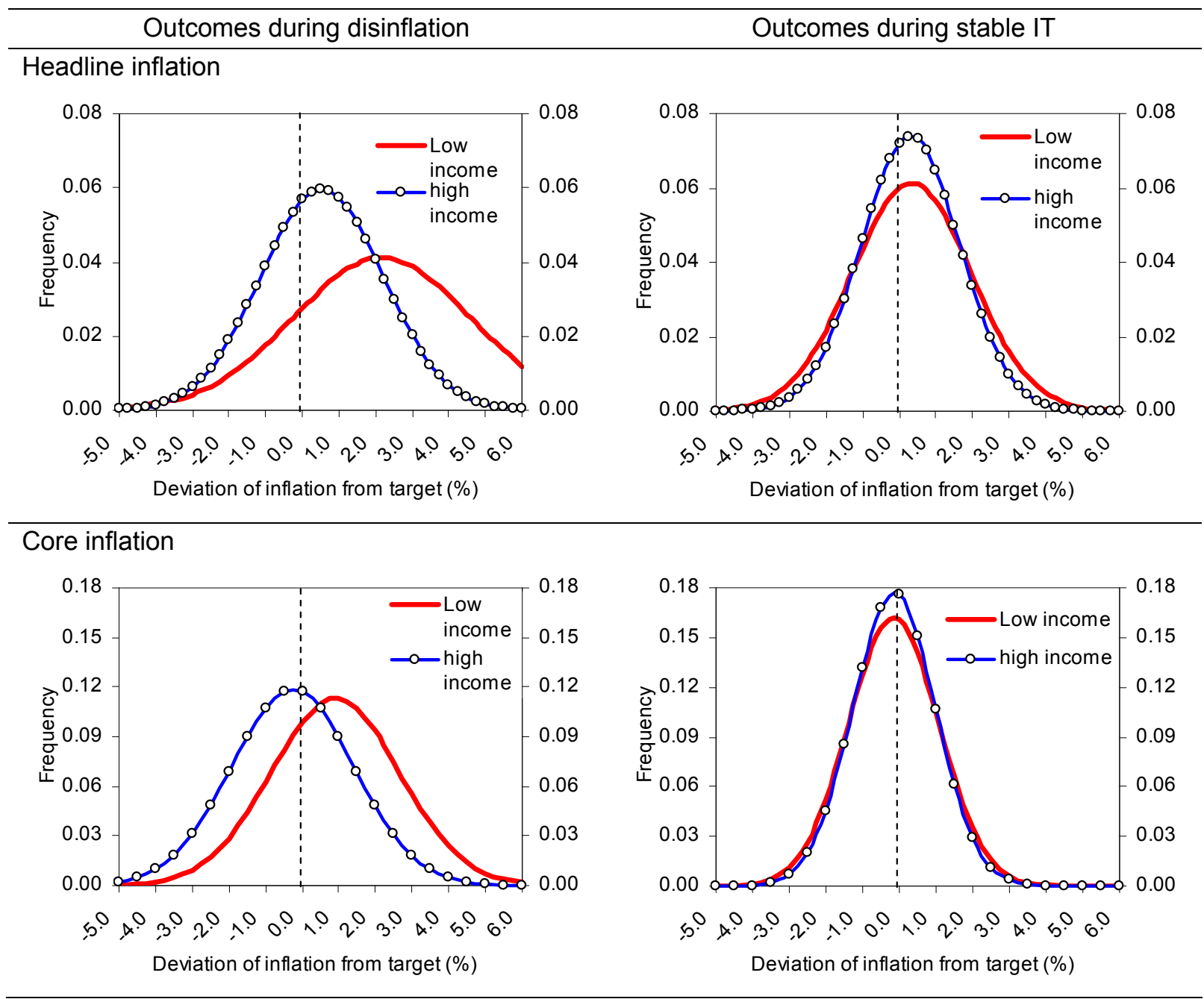

Source: Author's calculations.

\section{Econometric analyses of deviations of inflation from targets help to account for}

these results. In particular, Albagli and Schmidt-Hebbel (2004), Lostumbo (2007), and Gosselin (2007) all find that policy credibility has an important effect on the volatility of inflation around the target. The higher frequency, magnitude, and persistence of target misses during disinflation are likely in part to reflect relatively weak policy credibility during the early stages of IT. Céspedes and Soto (2005) also note that with weak credibility, the outputinflation trade-off is worse. In such circumstances, monetary policy responses to supply shocks will tend to be more muted than otherwise, which results in larger and more persistent deviations of inflation from target. The analyses also find that relative price shocks, including significant movements in exchange rates and energy prices are also important accounting for deviations of inflation from targets. 


\section{B. Macroeconomic Performance Under Alternative Monetary Policy Regimes}

25. Comparing macroeconomic performances under alternative monetary policies is a challenging task. A critical issue in making comparisons is the selection of relevant comparators. As discussed in Vega and Winkelried (2005), the ideal analysis would compare performance in countries which adopted IT with how they would have performed had they not adopted IT. Since this is not possible, the challenge is to find another group of countries that can be used as relevant comparators.

26. There is likely to be some self-selection among countries adopting IT. That is, countries with conditions more suited to IT may be more likely to adopt it, making comparisons with non-targeters more difficult. Mishkin and Schmidt-Hebbel (2005) emphasize that the selection of comparators should take into account the endogeneity of the decision to adopt IT. However, this aspect may be overemphasized in so far as many adopters of IT did so in crisis circumstances, as noted earlier, rather than deliberately. Moreover, as Batini and Laxton (2005) document, countries adopting IT often did not have in place many of the conditions regarded as important requirements for successful IT.

\section{The main differences in the results in the various papers making such comparisons largely reflect differences in the selection of comparator countries:}

- The IMF (2005) analysis is based on a comparison of performance in the then 13 emerging market inflation targeters with 29 non-IT emerging market countries. ${ }^{19}$

- Mishkin and Schmidt-Hebbel (2005) compare performance in the same group of emerging market economies with a number of alternative control groups. One control group includes 13 non-IT industrial countries, deliberately established to provide a best (non-IT) benchmark. ${ }^{20} \mathrm{~A}$ second control group adds the pre-IT experience of subsequent IT countries to make the comparison more realistic. The authors also seek to adjust for the endogeneity of the adoption of IT by using a parsimonious instrumental variable technique.

\footnotetext{
${ }^{19}$ These included 22 non-IT countries in the JP Morgan Emerging Market Bond Index (Algeria, Argentina, P.R. China (mainland), Côte d'Ivoire, Croatia, Dominican Republic, Ecuador, Egypt, El Salvador, Indonesia, Lebanon, Malaysia, Morocco, Nigeria, Pakistan, Russia, Serbia, Tunisia, Turkey, Ukraine, Uruguay, and Venezuela) plus seven similarly classified countries (Botswana, Costa Rica, Ghana, Guatemala, India, Jordan, and Tanzania).

${ }^{20}$ Described as a "selective set of countries that are at the international frontier of macroeconomic management and performance: Austria, Belgium, Denmark, France, Germany, Greece, Ireland, Italy, Japan, Luxembourg, Netherlands, Portugal, and the United States."
} 
- Vega and Winkelried (2005) compare the performance of all inflation targeters, including both industrial and non-industrial countries, with a group of 86 non-IT countries. To match IT country performances to relevant comparators, the authors use a "propensity score matching" approach that seeks to identify relevant comparators for each IT country by comparing their pre-IT performance on a range of macroeconomic criteria with corresponding performance of countries that did not adopt IT.

28. A second important issue is how to control for external factors. In this regard, the analyses are fairly consistent in approach: (a) using similar starting dates for adoption of IT by the various IT countries; and (b) using the average date of IT adoption by the relevant group as a breakpoint for comparing performances of non-IT countries. ${ }^{21}$ This helps to minimize the influence of developments in the global economic environment on the relative performance of the different policy frameworks.

\section{In this paper, updated comparisons are based on essentially the same country} groups as in the IMF 2005 analysis. ${ }^{22}$ A comparison of macroeconomic performances suggests that low income economies that have adopted IT have outperformed low income economies with other policy regimes. Figure 4 compares inflation and growth performances of high and low income IT and non-IT countries, in the 1990s and 2000s. In the case of the low income IT countries, the macroeconomic performance indicators for the earlier period correspond to their pre-IT regimes, while the figures for the later period cover their experience under IT. ${ }^{23}$ The left panel shows changes in performance in terms of inflation and growth rates, while the right panel shows performance in terms of inflation and output volatility.

\footnotetext{
${ }^{21}$ The end-1999 breakpoint used in the analyses reflected the fact that the average and median number of quarters of experience with IT among emerging markets at the time corresponded to the beginning of 2000.

22 The difference between the groups used in this analysis and the IMF 2005 analysis (described in footnote 19) are as follows: (i) the group of non-IT economies excludes Guatemala, Ghana, Indonesia, Serbia, and Turkey, which have subsequently adopted IT, while (ii) Bulgaria has also been added to the group of relevant non-IT comparators. For high income IT economies, the group of comparator non-IT economies includes Cyprus, Denmark, the euro area, Hong Kong SAR, Japan, Singapore, Slovenia, Switzerland, Taiwan POC, and the United States. Additionally, the data sample is extended to end-2008, and the breakpoint between the earlier and later periods is shifted by one year (to the end of 2000) to reflect the change in the median date for adoption of IT.

${ }^{23}$ For IT countries, the sample periods are split pre-and post IT adoption while for non-IT countries the split is set at the end of 2000, corresponding to the median adoption date of IT for the countries adopting IT.
} 
Figure 4. Inflation and Growth Performances: 2001-2008 vs. 1991-2000

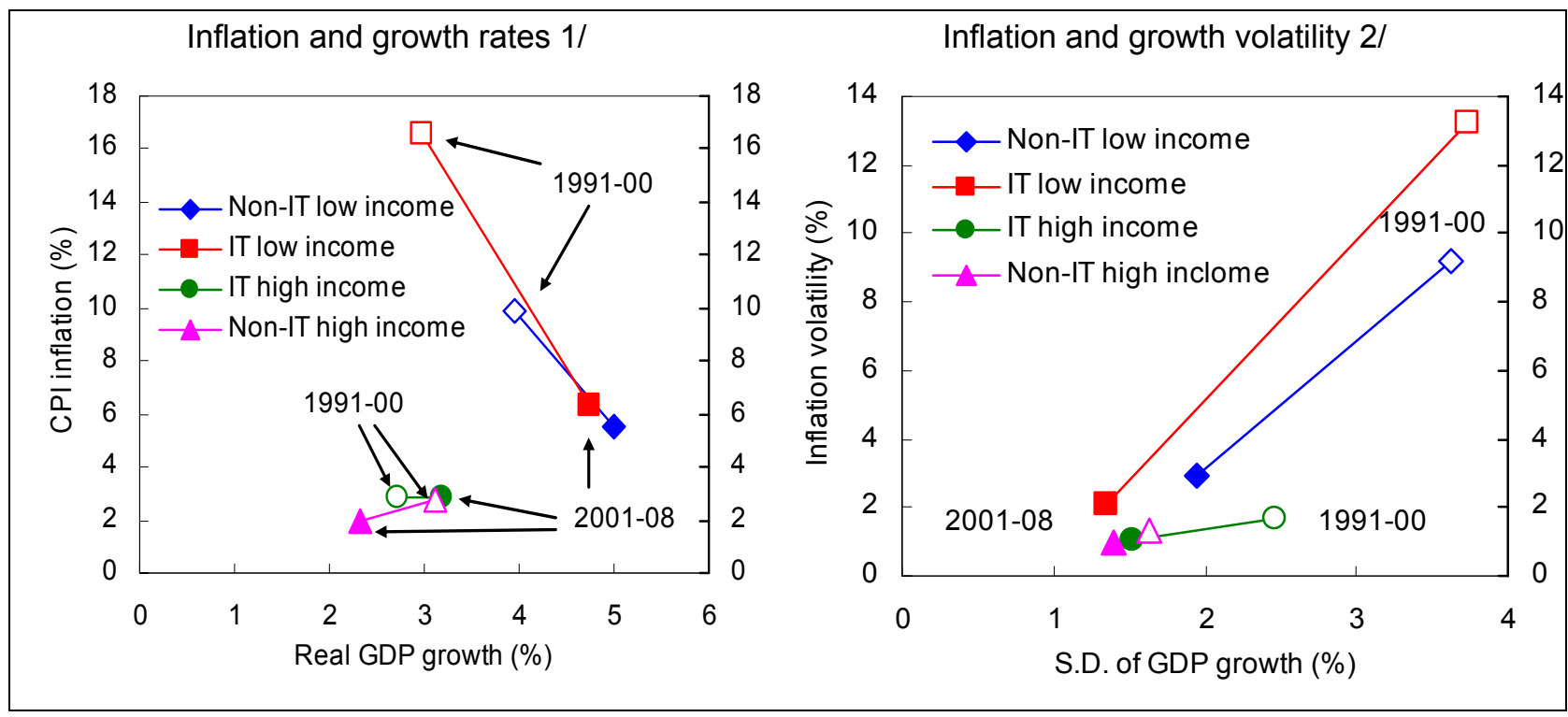

Source: Author's calculations.

1/ Figures based on median country values of median annual values for inflation, and averages of median values for growth.

2/ Figures based on median country values of standard deviation of annual percentage changes.

30. The figures indicate that:

- Both IT and non-IT low income countries saw major reductions in inflation rates, together with improvements in growth rates, but the countries adopting IT saw larger improvements in both dimensions. The typical reduction in inflation in the low income IT countries was 5.8 percentage points relative to the reduction in non-IT countries, while the relative improvement in growth was 0.7 percentage points. Among the high income countries, both IT and non-IT countries maintained low inflation rates, but the IT countries experienced a modest increase in growth, while non-IT countries typically experienced a decline in growth.

- Both low income groups also experienced large reductions in the volatility of inflation and output, with the countries adopting IT again registering the biggest reductions in both kinds of volatility. Typically, the low income IT countries experienced a 4.9 percentage point decline in the standard deviation of inflation relative to non-IT low income countries, and a 0.7 percentage point reduction in relative growth volatility. Among the high income countries, the performance of IT countries converged on the good performance of the non-IT countries. 
31. More formal statistical analyses of the benefits of adopting IT are also based on a "difference in differences" approach, comparing how performance for key macroeconomic variables has changed in countries adopting IT with performance in other countries under alternative monetary regimes over the same period. Ball and Sheridan (2003) applied this approach to industrial countries, and found no significant benefit from the adoption of IT. However, using similar methodology, Mishkin and Schmidt-Hebbel (2005), IMF (2005), and Vega and Winkelried (2005) have found clearer evidence that IT in emerging market economies has been associated with better macroeconomic performance than alternative policy regimes.

32. The results of these analyses suggest that, when otherwise similar countries are compared over the same time periods, countries adopting IT have tended to out-perform non-IT countries. The results from the IMF (2005) analysis are indicative. Over the period and countries examined, IT has been associated with a 4.8 percentage point reduction in average inflation relative to other monetary policy regimes. Interestingly, this is very close to the figures obtained by Mishkin and Schmidt-Hebbel (2005) and by Vega and Winkelried (2005). ${ }^{24}$ IT was also associated with a reduction in the variability of inflation (as measured by the standard deviation of inflation) by 3.6 percentage points relative to other strategies.

\section{The Resilience of Inflation Targeting}

\section{An issue of particular relevance in the wake of the global commodity price and} financial shocks of the past two years is whether IT is more robust to shocks than other policy frameworks. Throughout most of the period since IT was widely adopted, global macroeconomic conditions have been relatively benign compared with earlier periods. As a result, there is only limited evidence on the robustness of IT regimes to major shocks. The major examples prior to 2007 included the impact of the Argentina crisis on Brazil and other Latin American inflation targeters, Brazil's political crisis in 2002, South Africa's experience with a loss of investor confidence and sharp currency depreciation in 2001-02, and Hungary which faced a massive fiscal shock in $2002 .{ }^{25}$ Shocks of similar magnitude have destabilized

\footnotetext{
${ }^{24}$ The most comparable result in the Mishkin and Schmidt-Hebbel analysis is from the use of IV with the Control 1 group of countries, to maximize allowance for the fact that the emerging market countries adopting IT have generally been far from the frontier of macroeconomic management. In this case, the authors obtain the same estimated reduction in inflation due to adoption of IT: 4.8 percent. In the Vega and Winkelried analysis, the relevant comparisons are for developing countries adopting full-fledged IT. Their estimates of the benefit of adoption of IT in terms of inflation reduction fall in the range of 3.3 to 5.4 percentage points.

${ }^{25}$ See Bevilaqua and Loyo (2004) for a discussion of how Brazil's fledgling IT regime was stress-tested in the first few years after its introduction.
} 
these countries in the past, suggesting that the framework has contributed to the economies' resilience to shocks.

34. How well have IT frameworks performed in handling the 2007-2008 global commodity price and financial shocks? It goes beyond the scope of this paper to address this issue in depth. Moreover, in the case of the global financial shock, the full effects on macroeconomies are far from over. Consequently, this paper offers only a very preliminary and limited perspective.

\section{IT countries appear to have done better than others in minimizing the} inflationary impact of the surge in commodity prices in 2007. ${ }^{26}$ As shown in Figure 5, all country groups saw significant increases in inflation and declines in growth. However, the low income non-IT countries experienced twice as big an increase in inflation as the low income IT countries (4.7 percentage points versus 2.3 percentage points), even though their GDP growth rates fell by very similar amounts (down 1.3 percentage points in the non-IT countries, versus 1.6 percentage points in the IT countries). Among the high income countries, IT countries had a smaller decline in growth than non-IT countries (down 2.5 percentage points versus 3 percentage points) and slightly less of an increase in inflation (up an average of 1.9 percentage points versus 2.1 percentage points). These

Figure 5: Inflation and growth rates, 2006-08 $1 /$

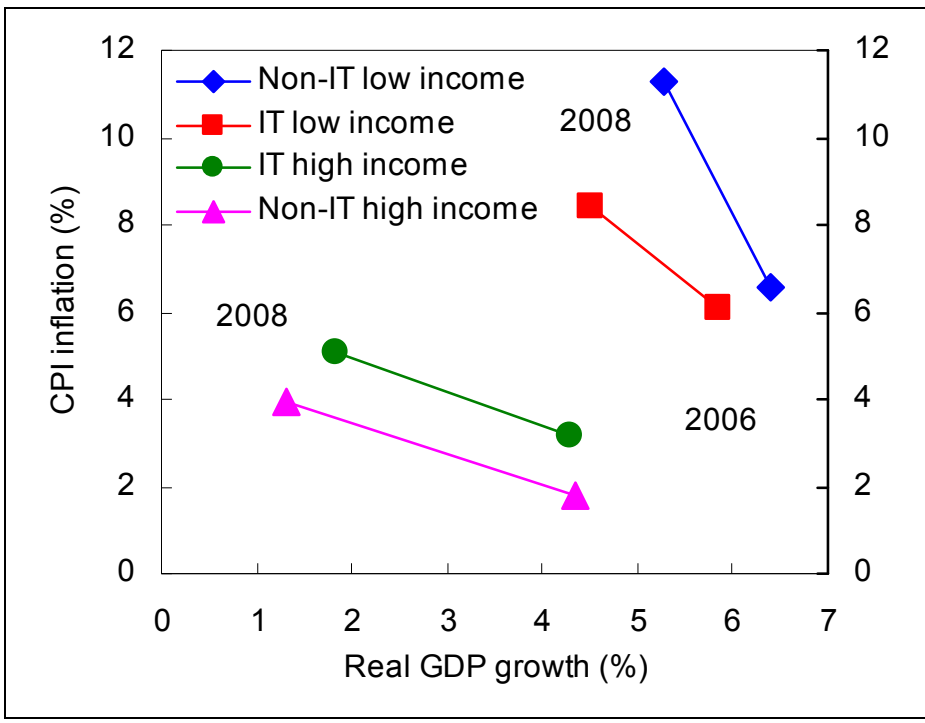

Source: Author's calculations.

$1 /$ Averages of annual percentage changes. results are consistent with inflation expectations being better anchored in the IT countries, and also with the authorities placing a greater emphasis on keeping inflation from surging, but more careful analysis will be needed to disentangle these effects from other influences on growth and inflation, before any solid conclusions can be reached.

36. The impact of the global financial crisis is still unfolding so it is premature to judge whether inflation targeters have coped better than others. To be sure, several IT

\footnotetext{
${ }^{26}$ Habermeier and others (2009) provide a comprehensive discussion of the inflation surge and monetary policy responses in emerging market and developing economies.
} 
countries have been amongst the hardest hit by the crisis, and several have entered into IMF supported programs. ${ }^{27}$ However, it is not at all clear that IT made these countries more susceptible to crises, or that their macroeconomic downturns are more severe than in comparable countries with other policy regimes. Indeed, there is some evidence to suggest that the IT countries are expected by market participants and private sector forecasters to weather the crisis somewhat better than non-IT countries.

\section{Credit default swap (CDS)} spreads suggest that IT countries are expected to be less vulnerable to fullblown financial or exchange rate crises. Figure 6 shows the evolution of CDS spreads in low income non-IT countries as well as in low and high income IT countries. In $2007 \mathrm{H} 2$, spreads for low income countries were very similar, at 50-60 basis points. Spreads increased gradually through 2008, but remained similar until the eruption of the full-blown crisis in October 2008. Although spreads for both groups, as well as high income countries rose sharply, spreads for low income non-IT countries rose to around 100 basis points over those of low income IT countries. This suggests that market participants viewed, and continue to view non-IT countries as riskier than IT countries. Of course, several other factors may play an important role in explaining the evolution of CDS differentials, but they may also reflect a difference in the perceived resilience of IT policy frameworks.

\footnotetext{
27 These include Iceland, Hungary, Romania, and Serbia.
} 
38. Macroeconomic forecasts also suggest that IT economies are expected to be less adversely affected by the effects of the financial crisis (Figure 7). June 2009 Consensus Economics forecasts indicate that average growth for all groups of countries in 2009-10 is expected to fall well below typical growth experienced in the 2001-08 period. Together with declines in commodity prices, this is expected to lead to below average inflation. Median inflation is projected to fall by close to 2 percentage points in low income countries, and by close to 0.9 percentage points in high income countries. Forecast differences between IT and non-IT countries are
Figure 7: Growth and inflation: 2009-10 forecasts vs. 2001-08 performance $1 /$

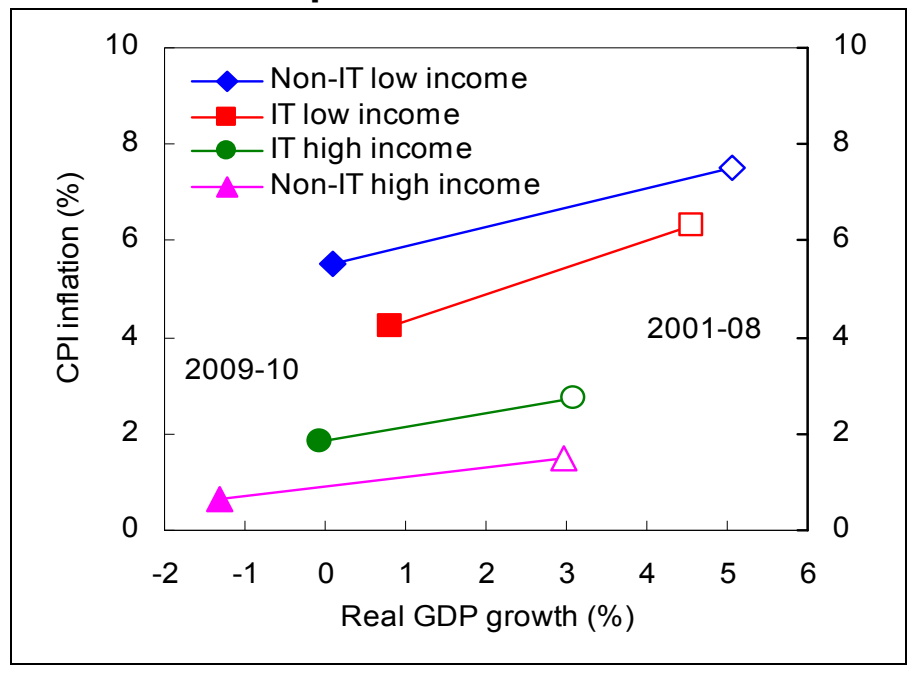

Source: Author's calculations.

1/ Median country values; forecasts use June 2009 Consensus Economics forecasts. negligible. Non-IT countries, however, are forecast to experience larger declines in growth. Among low income countries, median growth in non-IT countries is forecast to fall by 5 percentage points versus 3.8 percentage points in IT countries. Among high income countries, growth is forecast to fall by 4.3 percentage points in non-IT countries versus 3.1 percentage points in IT countries.

\section{ISSUES AND CHALLENGES FOR INFLATION TARGETING}

39. Although the evidence to date suggests that IT can perform well in many quite different kinds of economies, a number of issues and challenges arise for the future. Given the growing number of emerging market and developing economies adopting IT, a key challenge is to adapt the framework to their circumstances. The second crucial challenge, relevant for all countries, is how to take better account of financial structures and vulnerabilities in the IT framework.

\section{A. Adapting Inflation Targeting to Emerging Market and Developing Countries ${ }^{28}$}

40. Emerging market and developing countries adopting IT face a number of challenges that differ in character or in degree from those faced in more advanced

\footnotetext{
${ }^{28}$ See also Batini and others (2006).
} 
industrial economies. Calvo and Mishkin (2003) highlight five particularly important challenges for non-industrial countries. These include: (i) weak public sector financial management; (ii) weak financial sector institutions and markets; (iii) low monetary policy credibility; (iv) extensive dollarization of financial liabilities; and (v) vulnerability to sharp changes in capital flows and international investor sentiment. ${ }^{29}$ In addition, many of these countries face considerably greater uncertainty about the structure of their economies, the monetary policy transmission mechanism, and the cyclical position of the economy than is typical of industrial country inflation targeters. These challenges are discussed in turn below.

41. The credibility of any systematic monetary policy framework requires bringing public sector finances under control. Fiscal dominance, or the threat of it, may completely undermine the credibility of inflations targeting. Indeed, fiscal policy that is fundamentally inconsistent with the inflation target can trigger an exchange rate crisis just as it may lead to the collapse of an exchange rate peg. However, it is also possible that adoption of IT may serve as a catalyst for public sector financial reform precisely by highlighting the inconsistency of fiscal indiscipline with the goal of stable, low inflation.

\section{Adoption of IT as part of a more comprehensive package of economic reforms} complicates the conduct of monetary policy. Such reforms often involve structural changes affecting long run equilibrium values and dynamics of key macroeconomic variables, making it extremely difficult to forecast or react with any degree of policy precision to economic developments. These challenges are often compounded by lack of good quality, timely macroeconomic data. Such complications do not necessarily preclude IT, ${ }^{30}$ but they do imply that achieving targets is likely to be particularly challenging, as appears to be borne out by the earlier evidence on the high frequency of target misses during disinflation. In such circumstances, countries might opt for relatively wide target ranges until the structure of the economy has settled down and policy transmission is better understood. In addition, a high premium needs to be placed on policy transparency and accountability in order to ensure that target misses are not misinterpreted as reflecting lack of policy commitment.

\section{Weak financial sector institutions and markets need to be taken into account in formulating and implementing IT. As discussed in Laurens and others (2005), such} weaknesses alter the relative efficiency and speed of monetary policy transmission through different channels, and these need to be taken into consideration in policy formulation, on a country-by-country basis. Weak or incomplete financial markets may also limit the scope for reliance on the use of market-based instruments for implementing policy, but this is not essential. What is essential, is for the central bank to be able to move the interest rates faced

\footnotetext{
${ }^{29}$ See also Fraga, Goldfajn, and Minella (2003).

${ }^{30}$ See Batini and Laxton (2005).
} 
by households and businesses, and to do so in a manner that is clearly linked to the inflation objective. Weaknesses in the financial system itself may complicate the conduct of IT, as with any other monetary policy. In such circumstances, development of the IT framework should also entail prudential measures and other reforms to strengthen the financial system.

\section{The role of the exchange rate in an IT framework is a particularly important} issue for emerging markets and developing economies. ${ }^{31}$ The conventional wisdom has long been that an IT central banks should not react directly to exchange rate movements, but only insofar as they affect the outlook for inflation and output. ${ }^{32}$ Such a benign approach to the exchange rate may not be appropriate, however, in economies where there is a high degree of liability dollarization, or where access to international financial markets is limited. The global financial crisis has highlighted the importance of financial vulnerability and high dollarization for emerging market inflation targeters. As noted by Mishkin (2003), extensive dollarization of the economy can substantially alter the transmission of monetary policy. In particular, high dollarization of the financial system will tend to amplify the importance of exchange rate changes relative to domestic interest rate movements in policy transmission, and may generate aggregate demand effects opposite to those in industrial countries. A number of highly euroized economies in Central and Eastern Europe appear to be encountering precisely this type of problem. In such circumstances, leaning against exchange rate movements may improve macroeconomic performance under IT, as long as the degree of exchange rate dampening is low. ${ }^{33}$

\section{B. Inflation Targeting and Financial Stability}

\section{The global financial crisis is forcing central banks to re-assess the relationship} between monetary and financial stability policies. To some extent, the assessment of what should be done depends on a diagnosis of the underlying causes of the crisis. One line of argument is basically that monetary policy in the United States and the euro area was too loose for too long, and that this fueled housing price bubbles in both regions. ${ }^{34}$ An alternative argument is that the crisis is a consequence of monetary policy in the major economies being too narrowly focused on medium-term inflation, paying insufficient attention to financial developments and their implications for longer-term inflation risks. ${ }^{35} \mathrm{~A}$ third line of argument

\footnotetext{
${ }^{31}$ See Stone and others (2009) for an extensive overview of the role of the exchange rate in emerging market economies.

${ }^{32}$ See Taylor (2001) for a succinct summary of the literature on this issue up to that point.

${ }^{33}$ See Céspedes and others (2004), Morón and Winkelried (2005), and Roger and others (2009).

${ }^{34}$ Taylor (2009).

${ }^{35}$ See e.g., Borio and Lowe (2002) “Asset prices, financial and monetary stability: exploring the nexus," BIS Working Paper No. 114.
} 
is that financial sector deregulation and regulatory arbitrage led to a loosening of monetary conditions in the United States and elsewhere that was not adequately taken into account in setting monetary policy.

\section{The issue of whether or how monetary policy should respond to financial} stability development is analogous to the issue of responding to exchange rate developments. From this perspective, it could be argued that there is unlikely to be much benefit from responding directly to financial sector developments, such as asset price changes, but there could be some benefit from an indirect response to the extent that financial sector developments affect the outlook for excess demand and inflation. ${ }^{36}$ This line of argument is reasonable to the extent that financial sector developments are, in fact, captured in the macroeconomic analysis and forecasts of central banks. The plain fact, however, is that most IT central banks' analytical frameworks are seriously deficient with regard to macrofinancial interactions.

\section{At a minimum, the crisis highlights the need for IT countries to pay greater} attention to macro-financial interactions. In virtually all IT economies, the workhorse macroeconomic models used in monetary policy analysis and forecasting lack any substantial representation of the financial sector, determination of key asset prices such as equity and property prices, or interaction between the financial sector and household and corporate sector behavior. Nor is there any representation of interaction within the financial sector. Remedying such weaknesses will not be easy, but will be important if financial developments are to be better integrated into policy analysis and forecasting.

\section{A possible alternative is for central banks to react directly to financial stability}

indicators. ${ }^{37}$ In other words, some indicator of financial stability would enter the central bank's reaction function directly. If the financial sector is already adequately represented in the central bank's policy model, then reacting directly to financial indicators might worsen macroeconomic performance, at least for some types of shocks. If the financial sector is not properly captured in the model, then reacting directly to financial indicators might improve performance. Walsh (2009) argues that reacting to financial indicators can be welfare improving if financial frictions give rise to economic distortions, analogous to the rationale for including output in the policy reaction function. Research is needed in this area, including determining what would be the appropriate financial indicators to take into account, and how to include them in the central bank's reaction function.

\footnotetext{
${ }^{36}$ Bernanke and Gertler (2001) and Bean (2004).

${ }^{37}$ See e.g., Borio and Lowe (2002) or Cecchetti and others (2000).
} 
49. Another possibility is to extend the IT horizon so as to be able to take into account the longer-term inflation risks associated with asset price cycles. ${ }^{38}$ An advantage of this approach is that it would be less mechanical than responding directly to asset prices (or some other financial stability indicator). Nonetheless, a number of practical challenges would need to be addressed. In particular, a lengthening of the forecast horizon would also require improving central banks' medium- to long-term forecasting capabilities. In addition, there would be issues to sort out in terms of the appropriate timing of actions to counter development of asset price bubbles. ${ }^{39}$ Policy communications would also need to be strengthened to ensure that the credibility of the central bank's long-term commitment to low and stable inflation is maintained.

50. A potential alternative or complement to extending the policy horizon would be to introduce an element of price path targeting. ${ }^{40}$ Price path targeting would in effect extend the monetary policy horizon in a way that might facilitate taking into account financial stability considerations, but in a manner that might more credibly ensure a longterm commitment to price stability. In addition, as noted by Walsh (2009), price path targeting would have important benefits in influencing the formation of expectations, which should help minimize potentially adverse effects of the zero lower bound on nominal interest rates.

\footnotetext{
${ }^{38}$ See e.g., Borio and Lowe (2002).

${ }^{39}$ See e.g., Bean (2004) and Gruen and others (2003).

${ }^{40}$ See e.g., Svensson (1999) and Ambler (2007).
} 


\section{References}

Albagli, Elías, and Klaus Schmidt-Hebbel, 2004, "By How Much and Why do Inflation Targeters Miss Their Targets?" Mimeo, Central Bank of Chile.

Ambler, Steve, 2007, "Price-Level Targeting and Stabilization Policy: A Review," Bank of Canada Discussion Paper 2007-11.

Ball, Laurence, and Niamh Sheridan, 2003,'Does Inflation Targeting Matter?" NBER Working Paper No. W9577.

Batini, Nicoletta, Peter Breuer, Kalpana Kochhar, and Scott Roger, 2006, "Inflation Targeting and the IMF," IMF Board Paper SM/06/33.

Batini, Nicoletta, and Douglas Laxton, 2005, "Under What Conditions Can Inflation Targeting Be Adopted? The Experience of Emerging Markets" in Klaus SchmidtHebbel and Fredric Mishkin (Eds.), 2005, Monetary Policy Under Inflation Targeting, (Santiago: Central Bank of Chile).

Bean, Charles, 2004, “Asset Prices, Financial Instability, and Monetary Policy,” American Economic Review 94(2), pp.14-18.

Bernanke, Ben and Mark Gertler, 2001, "Should Central Banks Respond to Movements in Asset Prices?” American Economic Review 91(2), pp. 253-57.

Bevilaqua, Afonso, and Eduardo Loyo, 2004, "Brazil's Stress Test of Inflation Targeting, BIS Papers 23.

Borio, Claudio, and Philip Lowe, 2002, "Asset prices, financial and monetary stability: exploring the nexus," BIS Working Paper 114.

Calvo, Guillermo, and Frederic Mishkin, 2003, "The Mirage of Exchange Rate Regimes for Emerging Market Countries," NBER Working Paper No. 9808.

Cecchetti, Stephen, Hans Genberg, John Lipsky, and Sushil Wadhwani, 2000, Asset Prices and Central Bank Policy, (Geneva and London: International Center for Monetary and Banking Studies).

Céspedes, Luis, Roberto Chang, and Andres Velasco, 2004, "Balance Sheets and Exchange Rate Policy" American Economic Review 94(4), pp. 1183-93.

Céspedes, Luis, and Claudio Soto, 2005, "Credibility and Inflation Targeting in an Emerging Market: Lessons from the Chilean Experience," International Finance 8(3), pp. 545575. 
Fraga, Arminio, Ilan Goldfajn, and Andre Minella, 2003, "Inflation Targeting in Emerging Market Economies," NBER Working Paper 10019.

Gosselin, Marc-André, 2007, "Central Bank Performance under Inflation Targeting," Bank of Canada Working Paper 2007-18.

Gruen, David, Michael Plumb, and Andrew Stone, 2003, "How Should Monetary Policy Respond to Asset-Price Bubbles?" in A. Richards and T. Robinson, eds., Asset Prices and Monetary Policy, (Sydney: Reserve Bank of Australia), pp. 260-80.

Habermeier, Karl, Inci Ötker, Luis Jácome, Alessandro Giustiniani, Kotaro Ishi, David Vávra, Turgut Kisinbay, and Francisco Vázquez, 2009, "Inflation Pressures and Monetary Policy Options in Emerging and Developing Countries: A Cross Regional Perspective," IMF Working Paper 09/1

Heenan, Geoffrey, Marcel Peter, and Scott Roger, 2006, "Implementing Inflation Targeting: Institutional Arrangements, Target Design, and Communications," IMF Working Paper 06/278.

Husain, Aasim, Ashoka Mody, and Kenneth Rogoff, 2005, "Exchange Rate Durability and Performance in Developing versus Advanced Economies," Journal of Monetary Economics 52, pp. 35-64.

International Monetary Fund, 2005, World Economic Outlook, (Washington: International Monetary Fund), September.

Laurens, Bernard, Marco Arnone, Alina Carare, George Iden, Kentaro Iwatsubo, Rodolfo Maino, Obert Nyawata, Andrea Schaechter, and Stephen Swaray, 2005, "Monetary Policy Implementation at Different Stages of Market Development," IMF Occasional Paper 244.

Lostumbo, Nicola, 2007, "Success in Hitting the Inflation Target: Good Luck or Good Policy?” Mimeo, Boston College.

Lybek, Tonny, and JoAnne Morris, 2004, "Central Bank Governance: A Survey of Boards and Management," IMF Working Paper 04/226.

Mishkin, Frederic, 2003, "Comments on Fraga, Goldfajn, and Minella, "Inflation Targeting in Emerging Market Economies,” NBER Macroeconomics Annual 2003. pp. 403-11. 
Mishkin, Frederic, 2004, "Can Inflation Targeting Work in Emerging Market Countries?" NBER Working Paper 10646.

Mishkin, Frederic, and Klaus Schmidt-Hebbel, 2005, "Does Inflation Targeting Make a Difference?" in Klaus Schmidt-Hebbel and Fredric Mishkin, eds., 2005, Monetary Policy Under Inflation Targeting, (Santiago: Central Bank of Chile).

Morón, Eduardo, and Diego Winkelried, 2005, "Monetary Policy Rules for Financially Vulnerable Economies," Journal of Development Economics 76, 25-51.

Reddell, Michael, 1999, "Origins and early development of the inflation target," Reserve Bank of New Zealand Bulletin 62(3), pp. 63-71.

Roger, Scott, and Mark Stone, 2005, “On Target: The International Experience with Achieving Inflation Targets,” IMF Working Paper 05/163.

Roger, Scott, Jorge Restrepo, and Carlos Garcia, 2009, “Hybrid Inflation Targeting Regimes," IMF Working Paper, forthcoming.

Stone, Mark, Scott Roger, Seiichi Shimizu, Anna Nordstrom, Turgut Kisinbay, and Jorge Restrepo, 2009, "What Role for the Exchange Rate for Emerging Market Inflation Targeting Countries?” IMF Occasional Paper 267, forthcoming.

Svensson, Lars, 1999, "Price-Level Targeting Versus Inflation Targeting: A Free Lunch?" Journal of Money, Credit, and Banking 31(3), pp. 277-95.

Taylor, John, 2001, "The Role of the Exchange Rate in Monetary Policy Rules," American Economic Review, 91(2), pp. 263-67.

Taylor, John (2009) "The financial crisis and the policy response: an empirical analysis of what went wrong” NBER Working Paper 14631.

Tuladhar, Anita, 2005, "Governance Structures and Decision Making Roles in Inflation Targeting Central Banks,” IMF Working Paper 05/183.

Vega, Marco, and Diego Winkelried, 2005, "Inflation Targeting and Inflation Behavior: A Successful Story?” International Journal of Central Banking, pp. 153-175.

Walsh, Carl, 2009, "Using monetary policy to stabilize economic activity," prepared for the Jackson Hole Symposium on Financial and Macroeconomic Policy, August 20-22, 2009. 
Wei, Dong, 2008, "Do Central Banks Respond to Exchange Rate Movements? Some New Evidence from Structural Estimation," Bank of Canada Working Paper 2008-24. 